\title{
Guns and gender-based violence in South Africa
}

\author{
Naeemah Abrahams, Rachel Jewkes, Shanaaz Mathews
}

\begin{abstract}
Background. The criminal use of firearms in South Africa is widespread and a major factor in the country having the thirdhighest homicide rate in the world. Violence is a common feature of South African society. A firearm in the home is a risk factor in intimate partner violence, but this has not been readily demonstrated in South Africa because of a lack of data.

Methods. We drew on several South African studies including national homicide studies, intimate partner studies, studies with male participants and studies from the justice sector, to discuss the role of gun ownership in gender-based violence.
\end{abstract}

Conclusion. Guns play a significant role in violence against women in South Africa, most notably in the killing of intimate partners. Although the overall homicide data suggest that death by shooting is decreasing, data for intimate partner violence are not readily available. We have no idea if the overall decrease in gunshot homicides applies to women in relationships, and therefore gun control should remain high on the legislative agenda.

S Afr Med J 2010; 100: 586-588.
Firearm-related crime has long been a feature of South African society, which has the third-highest annual rate of firearm deaths (26.8/100 000) after Colombia and Venezuela. ${ }^{1}$ The South African burden of disease study showed that homicide was the second leading cause of mortality and, although the overall number of homicides has decreased since 1994, gun-related murders remain the leading cause of violent deaths. ${ }^{2,3}$

Gun ownership is mainly a male phenomenon, a means to demonstrate manhood, particularly among young men. ${ }^{4}$ While men are the predominating victims of gun violence, women are most vulnerable behind closed doors, where guns are used to intimidate, control, hurt and kill intimate partners. An association between gun availability and homicides and suicides has been shown. A gun in the home is more likely to be used against a family member than in providing protection..$^{5-7}$ Femicide (female homicide) studies have shown that gun availability is a major risk factor in intimate femicide (murder by an intimate partner). ${ }^{8}$

Statistics for firearm use in South Africa are fragmented, with disaggregated firearm data last made available in 2000. ${ }^{9}$ While guns are often associated with South African security organisations, 6 times more guns are owned by civilians than by the state ( 3.7 million privately owned v. 567000 by police and army). ${ }^{10}$ More stringent firearm control legislation has gradually been implemented since 2000 to promote responsible ownership and possession. ${ }^{9}$ However, reports to parliament show that little is known about theft and loss of firearms from civilians and the state. ${ }^{9}$ With 3865 firearms reported lost by the police in 2006/7, control of state-owned guns is clearly

Gender \& Health Research Unit, Medical Research Council, Tygerberg, W Cape Naeemah Abrahams, MPH, PhD

Gender \& Health Research Unit, Medical Research Council, Pretoria Rachel Jewkes, MB BS, MSc, MFPHM, MD

Gender \& Health Research Unit, Medical Research Council, Cape Town Shanaaz Mathews, BSocSc (Hons), MPH poor. Crime statistics support this fact, with a parallel increase in illegal possession of firearms. ${ }^{9}$ Studies conducted in South Africa demonstrate the role of guns in gender-based violence.

\section{Methods}

We drew on 6 published studies: (i) a retrospective national female homicide study that detailed the mortality rates of women from intimate partner violence (IPV), including the manner of death. Data were gathered from a nationally representative sample of mortuaries and police dockets $(N=1052)$ on all homicides in 1999 of women aged 14 years and older; ${ }^{11-13}$ (ii) data from a random sample of 1 306 adult women living in the Eastern Cape, Northern Province and Mpumalanga describing prevalence and factors associated with $\mathrm{IPV}^{14}$ (iii) men's use of violence against their partners was studied by interviewing a random sample of men working for Cape Town Municipality; ${ }^{15,16}$ (iv) a sample of dockets $(N=2068)$ of rape cases reported to the police in Gauteng Province in 2003 was reviewed; ${ }^{17}$ $(v)$ aspects of male use of violence and masculinity were explored in a random sample of adult men $(N=1738)$ in the Eastern Cape and KwaZulu-Natal ${ }^{18}$ and (vi) the National Injury Mortality Surveillance System (NIMSS) study, which included data on firearm and non-firearm homicides rates from 2001 to 2004. The latter project produced and disseminated descriptive data for deaths from non-natural causes but did not collect data on perpetrators. Most mortuaries from which NIMSS collected data were urban-based, and the collated data from the 7 th annual report included firearm rates for all homicides in 4 cities (Cape Town, Johannesburg, Pretoria and Durban). ${ }^{20}$ These data also reflect the period when new firearm legislation was being implemented, and we used a regression model to test whether the changes between firearm homicides and nonfirearm homicide rates differed significantly for this period, using the rates as an outcome for the period and the cities.

\section{Use of guns on female murder victims}

Of the teenage and adult women killed in South Africa in 1999, 1147 (33.3\%) died from gunshot injuries (95\% confidence interval (CI) 23.7 - 42.9\%); $692(60.3 \%)$ of gunshot homicides occurred at home, with $405(30.6 \%)$ killed by an intimate partner (95\% CI $20.9-42.2 \%)$. We estimate the rate of females killed by shooting to be $7.5 / 100000$ population (95\% CI 4.2 - 10.7), which is more than 4 times the rate in the USA (1.54/ 100000 ). Indeed, the intimate femicide firearm rate (i.e. proportion of females shot and killed by their intimate partners) of 2.7/100 000 is higher than the overall USA rate of females killed by shooting, 
which was the highest among 25 high-income countries where firearms are widely available. ${ }^{21}$

A number of men who commit intimate femicide in which firearms are used, commit suicide after the killing. In South Africa, $19.4 \%$ of perpetrators commit suicide within a week of the murder (95\% CI 11.9 - 26.7\%).

Given that guns are lethal and easy to use, it is not surprising that $82.7 \%$ of victims were killed with a firearm..$^{12}$ Of the women victims of gun homicide, $67.4 \%$ were killed with a single shot, most often to the head and face (63.7\%).

\section{Use of guns on women in non-fatal incidents}

Interviews with a population-based sample of women also demonstrated the role of guns in violence against women where they were not used in fatal shootings. In the year before the threeprovince study, $1.5 \%$ of the women reported having been threatened or attacked with firearms, amounting to 150 firearm-related episodes per annum per 100000 women aged $18-49 .{ }^{14}$ In $25 \%$ of these cases, the perpetrator was a husband or ex-husband or boyfriend; this figure correlates with a study of working men in Cape Town, of whom 5\% disclosed that they had threatened a wife or a girlfriend with a gun. ${ }^{16}$

In South Africa, guns are not infrequently used in domestic violence, but exposure to such violence may also be causally related to gun ownership. Working men who had witnessed the abuse of their mothers were three times more likely to be arrested for illegal gun ownership as adults after adjustments for confounders; this study calculated that $30 \%$ of illegal gun possession would not have occurred if there had been no childhood exposure to domestic violence. ${ }^{15}$

Guns are often used in rape - in $40.9 \%$ of rapes of adult women reported to the police in Gauteng Province in 2003. Overall, a gun was the most commonly used weapon in $19.3 \%$ of all crimes comitted against adults. ${ }^{17}$

\section{Legal v. illegal guns}

A community-based sample of adult men showed that it was more common for them to possess an unlicensed gun (11\%) than a licensed one $(6 \%) ; 26.1 \%$ of the men who had committed rape $(27.6 \%$ of the sample) had both types of gun. Unlicensed gun ownership (26.1\% ) was more common among men who had ever raped than the equivalent figure of $6.2 \%$ among men who had not committed rape $(p<0.00){ }^{18}$ While the population-based research suggests that unlicensed gun ownership is more common than licensed, crude measures of 'ever possessed' may not indicate gun access and ownership, because the duration of unlicensed gun ownership may often be shorter than that of legal ownership. The illegal trading, network, markets and distribution of guns internationally and locally is complex, and diversions from the legal to the illegal markets are numerous, with large numbers of guns crossing national borders annually. The durability of guns makes their trade easy and policing a nightmare for countries such as South Africa with lax border and gun control. ${ }^{9}$ The national female homicide victim study also showed that there was no room for complacency about legal gun ownership, finding that perpetrators who legally owned guns were far more numerous than those having them illegally. Licensed guns were used in $74.4 \%$ of murders, and unlicensed guns in $25.6 \%$. While only $10 \%$ of the perpetrators of intimate femicide were security workers (police, armed forces and security guards), they possessed $47.4 \%$ of all the licensed firearms. ${ }^{19}$ Legal gun ownership was also found to be associated with suicide secondly after homicide, increasing the risk of suicide seven times, even after adjusting for social and demographic factors. The calculation of the population-attributable fraction found that $91.5 \%$ of murders followed by suicide would not have occurred were it not for legally owned guns. ${ }^{12}$ Strong associations between gun ownership and deaths of female partners have also been found in the USA. ${ }^{22}$

\section{The decline in gun homicide}

South Africa passed the Firearms Control Act (FCA) in 2000 to make firearm regulations covering private citizens, businesses and state institutions more stringent. Its aim was to promote more responsible ownership with stricter eligibility and competency requirements for state and civilian firearm licence applicants. More comprehensive criteria to declare a person unfit for possession of a firearm were also included. The application process calls for mandatory training and passing a test on the FCA regulations, including the handling and storage of firearms. Background checks are done on the mental stability of applicants and whether they have indulged in substance abuse or have a criminal record; this check can include interviews with intimate partners. Other regulations include the mandatory renewal of licences (depending on the type of firearm), increasing the age of applicants from 16 to 21 years, and limiting the number of firearms per person.

The FCA came into full effect in July 2004 although aspects of it were introduced from 2001. There is evidence that the changes in firearm laws have had an effect. Data from the 7th annual NIMSS report ${ }^{20}$ compare firearm homicide rates with non-firearm homicides

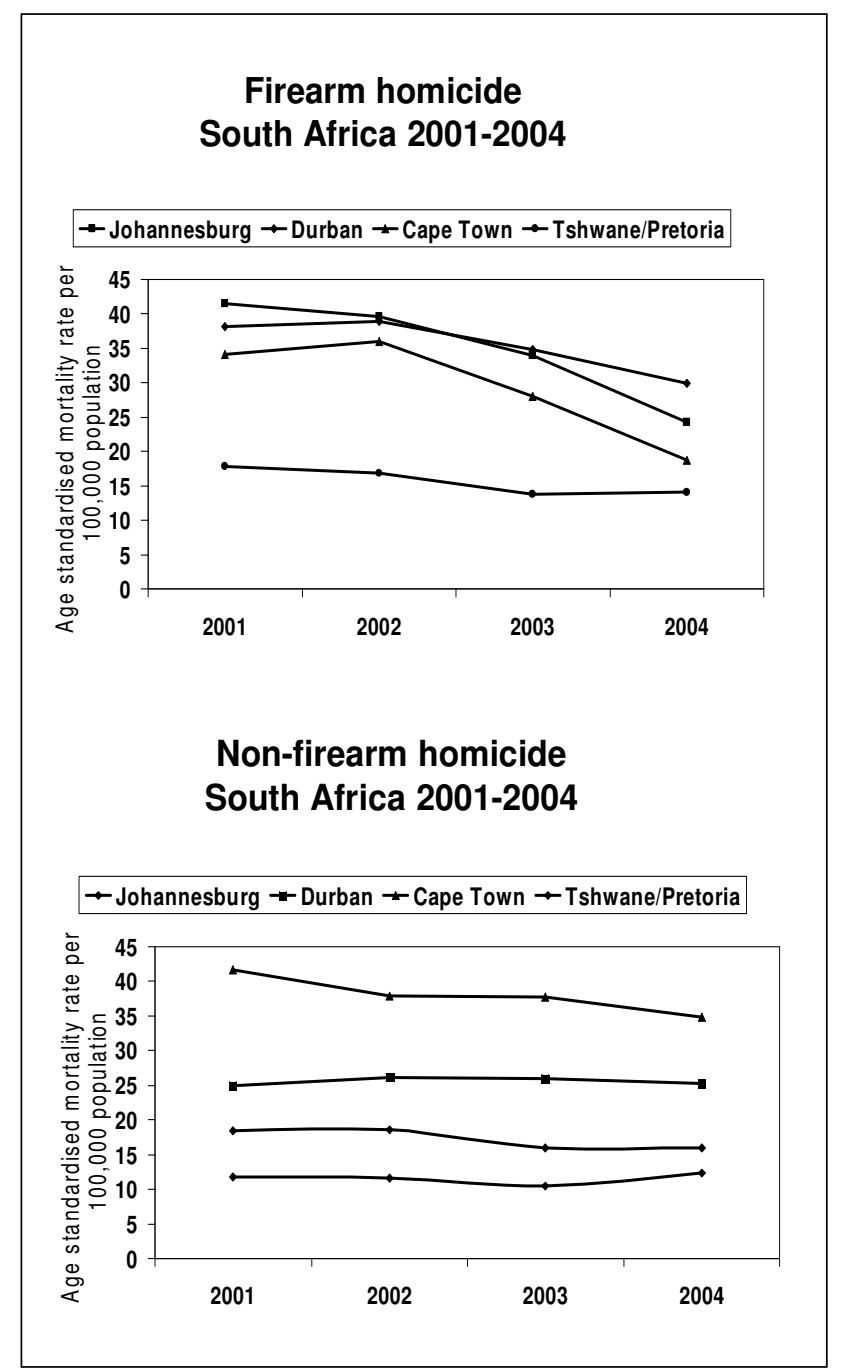

Fig. 1. Firearm mortality rates and non-firearm mortality rates for 4 cities in South Africa. ${ }^{20}$ 
rates for 2001 to 2004 (Fig. 1). Although a decline in both homicide rates is shown, there is a significantly faster decline for the firearm homicide group $(p<0.01)$. However, the femicide rate in 2004 was still 7 times more than that of the USA, which clearly shows that efforts must be increased to reinforce firearms control.

\section{Conclusion}

South Africa has the highest reported rate globally of females murdered by shooting in a country not engaged in war, and where men use guns to intimidate and assault women. In South Africa, illegal (i.e. unlicensed) firearms are more likely to be used in violent crime whereas legally owned firearms are the main risk factor for murder of intimate partners.

Developed countries that have reformed their gun laws within the last 10 years have seen the biggest benefit for women. ${ }^{23}$ The Firearms Control Act (No. 60 of 2000) came into effect in 2004, but aspects of it were implemented in 2000. Mortality data from Statistics SA and the NIMMS from 2000 show an overall steady decrease in the number of homicides and, in particular, those due to firearms. ${ }^{3,20}$ Limitations do not allow us to determine whether this decline includes femicide.

The FCA has commendable features to promote and ensure safer firearm use. However, the inability to apply it fully is a major obstacle in preventing violence against women in South Africa. To address this human rights problem, gun control should be part of a broader response to reducing violence within the home.

\section{References}

1. Cuiker W, Sidel VW. The Global Gun Epidemic: from Saturday Night Specials to AK47s. Santa Barbara, USA: Greenwood Publishing, 2006.

2. Bradshaw D, Groenewald P, Laubsher R, et al. Initial burden of disease estimates for South Africa 2000. S Afr Med J 2003; 93(9): 682-688.

3. Statistics SA. Adult Mortality (age 15 - 64) Based on Death Certification Data in South Africa: 1997 - 2004. Pretoria: Statistics SA, 2009.

4. Blumstein A. Youths, guns, and violent crime. Future Child 2002; 12(2): 3853.

5. Azrael D, Hemenway D. In the safety of your own home: results from a national survey on gun use at home. Soc Sci Med 2000; 50: 285-291.

6. Bailey JE, Kellermann AL, Somes GW, Banton JG, Rivara FP, Rushforth NP. Risk factors for violent death of women in their homes. Arch Intern Med 1997; 157: 777-782.

7. Campbell JC, Webster D, Koziol-McLain J, et al. Risk factors for femicide in abusive relationships: results from a multisite case control study. Am J Public Health 2003; 93(7): 1089-1097.

8. Campbell JC, Glass N, Sharps PW, Laughon K, Bloom T. Intimate partner homicide: review and implications of research and policy. Trauma Violence Abuse 2007; 8(3): 246-269.
9. Lamb G. 'Under the gun': An assessment of firearm crime and violence in South Africa. Report compiled for the Office of the President, Pretoria, 2008

10. Chetty R. Firearm use and distribution in South Africa. Pretoria: National Crime Prevention Centre, 2002.

11. Abrahams N, Martin LJ, Mathews S, Vetten L, Lombard C. Mortality of women from intimate partner violence in South Africa: A National Epidemiological Study. Violence Vict 2009; 24(4): 546-556.

12. Mathews S, Abrahams N, Jewkes R, Martin LJ, Lombard C, Vetten L. Intimate femicide-suicide in South Africa: a cross-sectional study. Bull World Health Organ 2008; 86(7): 542-558.

13. Mathews S, Abrahams N, Jewkes R, Martin LJ, Lombard C, Vetten L. Injury patterns of female homicide victims in South Africa. J Trauma 2009; 67(1): 168-172.

14. Jewkes R, Penn-Kekana L, Levin J, Ratsaka M, Schrieber M. Prevalence of emotional, physical and sexual abuse of women in three South African provinces. S Afr Med J 2001; 91(5): 421-428.

15. Abrahams N, Jewkes R. Effects of South African children's having witnessed abuse of their mothers during childhood on their levels of violence in adulthood. Am J Public Health 2005; 95(10): 1811-1816.

16. Abrahams N, Jewkes R, Laubscher R, Hoffman M. Intimate partner violence: Prevalence and risk factors for men in Cape Town, South Africa. Violence Vict 2006; 21(2): 247-263.

17. Jewkes R, Christofides N, Vetten L, Jina R, Sigsworth R, Loots L. Medico-legal findings, legal case progression, and outcomes in South African rape cases: retrospective review. PLoS Med 2009; 6(10): e1000164.

18. Jewkes R, Sikweyiya Y, Morrell R, Dunkle K. Understanding men's health and use of violence: interface of rape and HIV in South Africa. Cape Town: Medical Research Council, 2009.

19. Abrahams N, Mathews S, Jewkes R, Martin L, Vetten L. The role of guns in domestic violence: evidence from South Africa. Conference poster, International Injury Conference. Durban: 3 - 7 April 2006.

20. Prinsloo M, Kotzenberg C, Seedat M. A Profile of Fatal Injuries in South Africa: 7th Annual Report of the National Injury Mortality Surveillance System 2005. Cape Town: Medical Research Council/UNISA Crime, Violence and Injury Lead Programme, 2007.

21. Hemenway D, Shinoda-Tagawa T, Miller M. Firearm availability and female homicide victimization rates among 25 populous high-income countries. J Am Med Womens Assoc 2002; 57(2): 100-104.

22. Miller M, Azrael D, Hemenway D. Firearms availability and suicide, homicide, and unintentional firearm deaths among women. J Urban Health 2002; 79(1): 26-38.

23. Amnesty International Report 2005: The State of the World's Human Rights. London: Amnesty International, 2005.

Accepted 21 December 2009. 